\title{
The Effect of Outdoor Education on Cohesion of a Karate Team
}

\author{
Bella Eka Kusumawardani*, Novi Syaidatul Karimah, Rian Kurnia, Sagittarius Sagittarius \\ Sport Education Program, Postgraduate School \\ Universitas Pendidikan Indonesia \\ Bandung, Indonesia \\ *Bella1995@upi.edu
}

\begin{abstract}
The problems that the author adopted in this study is about the influence of the Cohesion Outdoor Education team sport athlete said in UKM karate UPI Bandung. Often seen less compact athlete during practice or during a match, it can be seen from the quality of athletes during exercise and when competing. Basically cohesion athletes are influenced by two factors, namely external and internal factors. The research method that will do the author is using the experimental method. The population in this study is the word karate team athletes that exist in SME Karate UPI Bandung which amounted to 12 people. Samples in this study as many as $\mathbf{1 2}$ people by using a sampling technique that total sampling. There are instruments used in this study, which is to measure the cohesion athletes team said the author using a questionnaire Current Status of Group Cohesion ScaleForm 1, Thomas (2001). Data processing techniques and data analysis using normality test and hypotheses test. The conclusion from this study is that exercise a significant influence on the Cohesion Outdoor Education team sport athlete said in UKM karate UPI Bandung. It is suggested to coaches, teachers, sports coaches, and the readers to try to improve the training of Outdoor Education, Cohesion athletes, especially in sports teams in the training program.
\end{abstract}

Keywords—outdoor education; cohesion; karate; athletes

\section{INTRODUCTION}

Research is depart from the problems found in the field is weak levels of the cohesiveness of athletes when did a sequence of The (move), especially on a branch of sport karate. According to the coach karate in the movement said (move) there is a sequence of a fairly complex as the motion in his hand and leg movements the same time. And this is done by some athletes to be in every game there are some athletes hard compact in his or her movements. For that athlete requires a lot of concentration, coordination and solidarity in the word (move) in order to the creation of a compact and nice to do.

This study departs from the problems found in the field, namely the weak level of cohesiveness of athletes when performing a series of Word movements (Kick), especially in karate sports. According to the karate trainers in the Kata movement (Kick) there is a series of movements that are quite complex such as hand movements and the same foot movements. The movement is difficult for some athletes to prove in every game there are some athletes who are difficult to compact in their movements. For this reason, athletes need good concentration, coordination and compactness in carrying out the Kata (Move) movement to create a compact and beautiful movement to do.

Karate comes from Chinese boxing martial arts created by Darma, Karate is a martial art originally from the Okinawa region, then modified and converted into a way of life by Gichin Funakoshi. Prior to this change, Karate-do was only an armless self-defense technique that only relied on hands and feet. Karate is a multi-complex sport, which is not only used as a martial art, but can also be used as a sports presentation. According to Nakayama's opinion cited by Muchsin that: "Karate is an empty-handed martial art where hands and feet are trained in a systematic way so that the sudden attack power of the enemy can be controlled by displaying a force such as using real weapons" [1]. In the beginning, karate was only a way of defending oneself from the interference of people who intended to harm or injure, starting from the way of attack and defense, which in general was in the form of horses, punches, kicks so arranged into a type of martial arts called karate. Along with the times, nowadays karate is heavily contested with the aim of finding potential karate athletes. In karate matches, the numbers contested are words (stance) and kumite (battles). The word is a series of basic movements in the form of punches, kicks, blocks that are strung together into a single form. The word is divided into individual words and team words, each of which consists of three people. While kumite is a practical application of the combination of karate movements / techniques commonly used during training.

Group cohesion itself is defined as how group members like each other and love one another, where the binding factors of the meaning of cohesion are the attractiveness of the group, the moral / level of motivation of each member and coordination of the efforts of group members. Some understanding of group cohesion a. Group Cohesion According to Collins and Raven defines group cohesiveness as a force that encourages group members to remain in the group and prevent them from leaving the group [2]. b. Group Cohesion Group cohesion is a feeling of being together in groups and is a force that nourishes and maintains members in groups. According to Taylor, Peplau and Sears defines cohesiveness as strength (both positive and negative) that causes members to remain in a group [3]. Cohesiveness depends on the level of individual attachment that each group member has. Interpersonal 
attractiveness is a positive principal force. c. Group Cohesion According to Hartinah defines group cohesion as a number of factors that influence group members to remain members of the group [4]. There are three meanings about group cohesiveness: (1) interest in the group including the feeling of not wanting to leave the group, (2) morality and level of motivation of group members, (3) coordination and cooperation between group members. One way to grow cohesion in groups is through an activity carried out together. A fun activity and done together is through Outdoor Education. In the activity Understanding Outdoor education is an activity outside the classroom / school such as playing in a school, garden, plantation, and this activity is an adventure that can develop the character and abilities of a child optimally. So, Outdoor education can be a medium to develop the potential of a child. Bogner stated that Outdoor Education stated that "Common sense dictates that frequently held conviction that experiences in the natural environment alone may contribute to improved environmental literacy. More than" normal "schools are likely to achieve" [5].

From the above statement, saying that experience in the wild can alone contribute more to improving education beyond what is expected to be achieved in a normal school. In Kardjono Outdoor education is divided into two different emphases, namely the first psycho-social pressure and the second on the task of nature and the environment [6]. Outdoor education which emphasizes on psycho-social Quoted from Neil and C. A Lewis [7] which is translated in Kardjono states that of the two definitions presented by them they can be listened to [6]. Outdoor education is an education that uses a person's overall development from observations and responses through feelings, hearing, sight, trials, touch and smell. Whereas Outdoor education which emphasizes on natural and environmental tasks is quoted from Lund [7], that has been translated by Kardjono states that Outdoor education is an experience learning method that uses all common sense through environmental deepening nature and place someone in relation to the late [6].

From his statement, it is said that life in the wild will require someone to jump directly in the face of various things that he must face. Therefore based on the problem that is the background of the weak level of cohesiveness of athletes when doing a series of Word movements (Kick), especially in karate sports.

\section{METHOD}

\section{A. Participant}

Participants are people who participate in an activity. Participants in this study were Kata Beregu athletes in the karate sports branch at UKM Karate UPI Bandung, totaling 12 people. The word team athlete chosen as the participant is an athlete, senior karate team member. Based on this, the author wants to provide treatment to improve coordination of group movements and strengthen cooperation especially cohesion through Outdoor Education to get better results.

\section{B. Procedur}

The research method used in this research is the experimental research method. With research design Pretest, treatment, and Posttest the One Group Prestest-Posttest Design. This research was conducted for Treatment in the form of Outdoor Education for 16 meetings.

\section{Instrument}

In a study to measure what we will examine, a research instrument or instrument is needed to obtain accurate information or data. According to Arikunto suggests that the research instrument is [8]: "The tools or facilities used by researchers in collecting data so that the work is easier and the results are better, in a more accurate, complete and systematic way so that it is easier to process". According to Sugiyono said that "Research instruments are a tool used to measure natural and social phenomena that are specifically observed in all these phenomena called research variables" [9]. From the opinion of the experts above it can be concluded that the research instrument is a tool used in research to facilitate obtaining accurate and systematic data, so that the results of the data obtained can be easily processed and concluded. The instrument used to collect data from the sample of this study was: Instrument to measure Group Cohesion Using Group Cohesion questionnaire.

\section{RESULT AND DISCUSSION}

A. The Graph Results of the Vote Count on Average Test Scores Early and Final Test on Those Kohesi the Athletes Said a Team

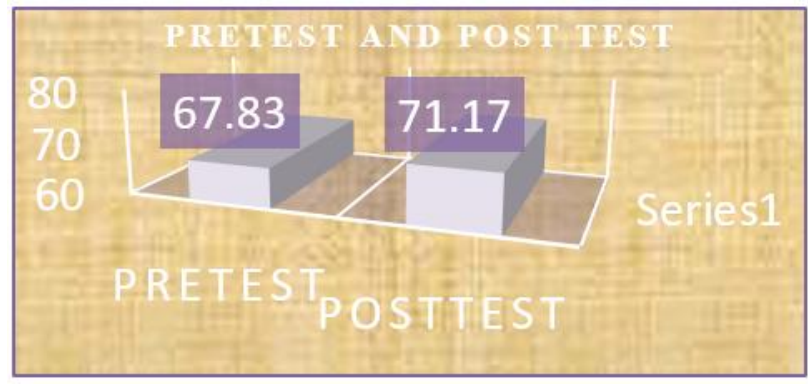

Fig. 1. Pretest and posttest.

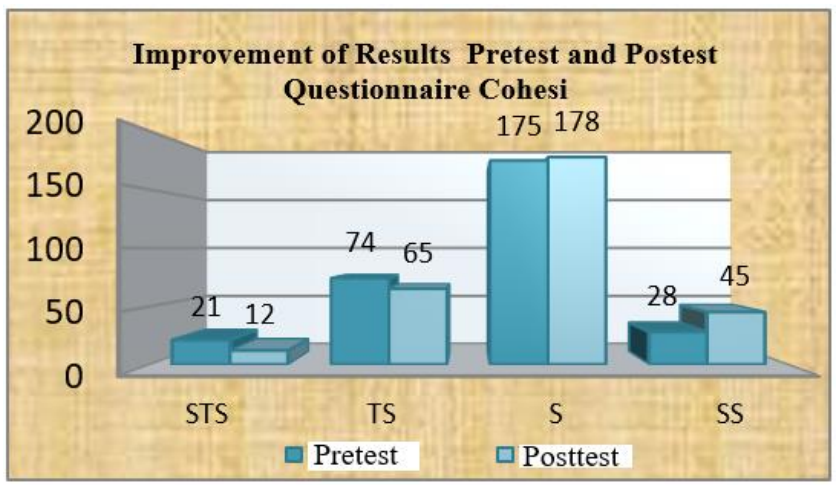

Fig. 2. Improvement of results pretest and postest questionnaire cohesi. 


\section{B. The Results Realibilitas}

TABLE I. ThE RESUlTs REALIBILITAS

\begin{tabular}{|c|c|}
\hline Cronbach's Alpha & N of Items \\
\hline .963 & 25 \\
\hline
\end{tabular}

TABLE II. THE TEST RESUlTS NORMALITY OF THE DATA ON VARIABLES KoHESI THE ATHLETES SAID A TEAM

\begin{tabular}{|c|c|l|l|}
\hline \multirow{2}{*}{$\mathbf{2}$} & Pretest & Posttest \\
\hline Normal Parametersa & Mean & 12 & 12 \\
\cline { 2 - 4 } & Std. Deviation & 67.83 & 71.17 \\
\hline \multirow{2}{*}{$\begin{array}{c}\text { Most Extreme } \\
\text { Differences }\end{array}$} & Absolute & .175 & .123 \\
\cline { 2 - 4 } & Positive & .175 & .123 \\
\cline { 2 - 4 } & Negative & -.091 & -.104 \\
\hline \multicolumn{2}{|c|}{ Kolmogorov-Smirnov Z } & .605 & .426 \\
\hline \multicolumn{2}{|c|}{ Asymp. Sig. (2-tailed) } & .858 & .993 \\
\hline
\end{tabular}

TABLE III. THE RESUlTS OF THE SCORE AN AVERAGE OF THE INITIAL TeSts, TEST, AND BRANCHING OFF AND ON THOSE KOHESI THE ATHLETES SAID A TEAM

\begin{tabular}{|l|l|l|l|l|l|}
\hline \multicolumn{7}{|c|}{ Descriptive Statistics } \\
\hline & $N$ & Mean & $\begin{array}{c}\text { Std. } \\
\text { Deviation }\end{array}$ & Minimum & Maximum \\
\hline Pretest & 12 & 67.83 & 3.614 & 63 & 75 \\
\hline Posttest & 12 & 71.17 & 2.691 & 67 & 75 \\
\hline
\end{tabular}

\section{The Test Results Normality of the Data on Variables Kohesi the Athletes Said a Team}

Based on the Table shows that the initial tests and an end to all variables, variables Kohesi the athletes said a team. The test results normality these data using a technique tests Kolmogorov Smirnov, shows that the probability or value of the $0,858>\alpha 0,05$ and $0,993>\alpha 0,05$. Means that the data on all variables in this study distribution. The test results paired simple t-test on those Kohesi the athletes said a team.

TABle IV. The Test Results Paired Simple T-Test on Those Kohesi the Athletes SAid a TeAm

\begin{tabular}{|c|c|c|c|c|c|c|c|c|}
\hline & \multicolumn{5}{|c|}{ Paired Differences } & \multirow[t]{3}{*}{$\mathbf{T}$} & \multirow[t]{3}{*}{ df } & \multirow[t]{3}{*}{ Sig. (2-tailed) } \\
\hline & \multirow[t]{2}{*}{ Mean } & \multirow[t]{2}{*}{$\begin{array}{c}\text { Std. } \\
\text { Deviation }\end{array}$} & \multirow[t]{2}{*}{$\begin{array}{c}\text { Std. Error } \\
\text { Mean }\end{array}$} & \multicolumn{2}{|c|}{$\begin{array}{l}\text { 95\% Confidence Interval of } \\
\text { the Difference }\end{array}$} & & & \\
\hline & & & & Lower & Upper & & & \\
\hline Pretest - Posttest & -3.333 & 2.425 & .700 & -4.874 & -1.793 & -4.762 & 11 & .001 \\
\hline
\end{tabular}

\section{The Test Results Paired Simple T-Test on Those Kohesi the} Athletes Said a Team

Criteria making decisions based on the value of the probability or the (sig.), namely : "If the value of the $>\alpha 0,05$ and then this means that $\mathrm{H} 0$, while if the value of the $<\alpha 0,05$ and then this means that $\mathrm{HO}$ be rejected. Based on the calculation results on the test that the value of significance on those research Kohesi the athletes said a team variables, 0.001 $<\alpha 0,05$. Therefore, this research can be concluded that: " There is a significant influence on the exercise Outdoors Education to Kohesi the athletes said a team on a branch of sport karate in loans for the karate UPI in Bandung.

$\mathrm{H}_{0}=$ No there is a significant influence of the Outdoors Education to Kohesi the athletes said a team on a branch of sport karate in loans for the karate UPI in Bandung.

$\mathrm{H}_{1}=$ There is a significant influence of the Outdoors Education to Kohesi the athletes said a team on a branch of sport karate in loans for the karate UPI in Bandung.

\section{CONCLUSION}

That from a study said there is a significant influence of the Outdoors Education to Kohesi's said a team sport karate in loans for the Karate UPI in Bandung.

\section{REFERENCES}

[1] M. N. Achmad and S. Muchsin, Best Karate Comprehensive. Cetakan Pertama 1980.

[2] B. E. Collins and B. H. Raven, "Group structure: Attraction, coalitions, communication, and power," The handbook of social psychology, vol. 4, pp. 102-204, 1969.

[3] S. E. Taylor, L. A. Peplau D. O. SEARs, "Behavior in groups," Social Psychology, vol. 9, no. 2, pp. 79-307, 1997.

[4] S. Hartinah, Konsep dasar bimbingan kelompok. Bandung: Refika Aditama, 2009.

[5] Bogner, "The influence of a residential outdoor education programme to pupil's environmental perception," European Journal of Psychology of Education,CV. Bintang Warliartika, 2002.

[6] Kardjono, Pengendalian Diri (Self Control) Melalui Outdoor Education, 2009

[7] J. Neill, Outdoor education in the schools: What can it achieve?. A pape presented to the 10th National Outdoor education Conference, Sydney, Australia, 1997.

[8] S. Arikunto, Penelitian tindakan. Yogyakarta: Aditya Media, 2010

[9] M. P. K. Sugiyono, Kualitatif, dan Kombinasi (Mixed Methods). Bandung: Alfabeta, 2013. 